African Journal for Physical, Health Education,

Recreation and Dance (AJPHERD)

Vol. 9, No. 2 (October) 2003, pp. 250-264.

\section{DEVELOPING A BODY OF KNOWLEDGE FOR SPORT MARKETING IN AFRICA}

\section{H. Van Heerden}

\section{ABSTRACT}

This paper aims to stimulate the development of a scienitic body of knowledge for sport marketing in Africa. A review of current journals indicates that African aeddemics are not devoing sufficient atterition to the developanent of a body of knowledge for sport marketing. In this paper three scenarios are formulated hat contextualise sport matketing as a muli-dinensional discupline. Research perspectives for each of the scenamos are proposed:

- Secratio 1 (morkenting of sporn). the marketing of sport prodicts and services. such as equipment and facthiles, which might be consumed by protessional athletes or amateurs:

- Scenario 2 (marketing hrough sport). the marketing of an organisation through its assoctation. such as a sponsorship, with sport events, teans or individuals; and

- Scenario 3 (marketing by sport) - the way sport bodles and codes market themselves and their events to attract sponsorships participants, spectators. funding, and corporate involverment

It is concluded that academics and practitioners should increase their effort to develop a body of knowledge for spont marketing in Africa.

Key words: Sport marketing, marketing of sport, marketing through sport, marketing by sport, corporate involvement

C.H. Van Heerden, Ph.D., Marketing Department of Marketing and Communication University of Pretoria 0002, South Africa

E-mail: chvanheerden@hakuna.up.ac.za
The marketing of sport is unique because sport services are unlike other products purchased by consumers - providers of the sport experience cannot predict the outcome, various events are inconsistent and results are uncertain" (Parks \& Zanger, 1990).

\section{INTRODUCTION}

It is doubtful if information on the size, scope and characteristics of the African sport industry has yet been published in any academic journal, although some information on the South African sport industry is available. This country's sport industry is quite substantial in money terms: In 2000 it contributed more than $\$ 1$ billion to the economy; it employed more than 30000 people directly; sport spectator expenditure capped the $\$ 80$ million mark and business expenditure reached $\$ 200$ million through inter alia direct sponsorship expenditure and indirect sponsorship support such as advertising. Close to 2 million South Africans actively participated in soccer while roughly $20 \%$ of the population ( 9 million) watched their favourite teams in action to make it South Africa's largest sport code.

Sport marketing as a field of scientific study in Africa has not yet reached first 


\section{VAN HEERDEN}

league status. Hardly any evidence of research has ever been published pertaining to sport marketing and sport sponsorship management in Africa. Very few African institutions offer sport marketing training programmes which means that marketing and business students are not exposed to this field of study. In 2001 the first ever doctorate degree was awarded in South Africa from a management or commercial faculty (van Heerden, 2001).

This paper therefore, aims to stimulate the process of developing a proper scientific body of knowledge relating to sport marketing in Africa.

\section{LITERATURE REVIEW}

A review of current marketing journals unfortunately indicates that academics in Africa are not devoting sufficient attention to the place of sport marketing in the overall corporate marketing strategy. Marketing scholars (as future managers who will make sponsorship decisions) have therefore not yet been exposed to any significant extent to sport marketing. This illustrates that sport marketing has not yet been accepted or critically evaluated as an important and relevant application of basic marketing as compared to other applications such as services marketing, industrial or business-to-business marketing, or retail marketing (Van Heerden, 2001).

Recent basic marketing texts such as Pride and Ferrel (1993), Bovée, Houston and Thill (1995), van der Walt, Strydom, Marx and Jooste (1996) and Kotler and Armstrong (1997) do not mention sport marketing at all. Other basic marketing texts (Van der Walt \& Machado, 1992; Dibb, Simkin, Pride \& Ferrel, 1994; Wilmshurst, 1995) discuss sponsorship as one of the instruments of the promotion mix. Only Solomon \& Stuart (1997) mentioned sport marketing (albeit very briefly). In journals and periodicals authors such as Thwaites (1995), Furlong (1994) and Meenaghan (1996) include sport sponsorship as one of the promotion elements of a broader sport marketing strategy. Incidentally, there are two international journals dedicated to sport marketing - the Sport Marketing Quarterly and the International Journal of Sports Marketing and Sponsorship.
More substantial discussions on sponsorships are found in texts on marketing communication (Dibb et al., 1994; Adcock, Bradfield, Halborg \& Ross, 1995; Wilmshurst 1995; Siegel, 1996). Bennett, Lamm \& Fry (1988) mention sponsorship as part of sales promotion; Belch \& Belch (2001) define event sponsorship as a consumer-orientated sales promotion; Cannon (1992) mentions sport as a promotion application on television. Lancaster \& Massingham (1993) mention sponsorship as a public relations technique and Hill (1994) discusses event sponsorship as a PR activity. Kotler (1994) identifies the sponsoring of a sport event as a major marketing public relations (MPR) tool. Zikmund and d'Amico (1996) view event sponsorship as a publicity generating and image-building exercise

It is therefore surmised from the above that there is a dire need for literatures in this vital area. African academics should produce marketing, marketing communication, sport marketing and sport sponsorship textbooks that serve the needs of African sport.

\section{A DEFINTION OF} SPORT MARKETING

Sport marketing as a theoretical construct has many confusing alternatives. Pitts and Stotlar (1996) state that "academicians have not yet agreed on what sport marketing is". Some texts create the impression that sport marketing equals sport sponsorship while uncertainty exists as to whether a unique sport-related marketing mix applies or whether sport marketing is an application from basic marketing such as retail marketing.

There is also lack of consensus on the correct terminology with regards to sport (singular) or sports (plural) marketing, which further confuses the issue. In this paper the term sport marketing (without an 's) is preferred. Mullin, Hardy and Sutton (1993) argue that "sports marketing" tends to characterise the industry as a mass of uncoordinated segments without commonality. The singular form is therefore preferred because all sport segments should be regarded as a homogeneous entity.

The first definition of sport(s) marketing was coined by Kesler (1979) and stated that sport marketing describes the activities 
of consumer and industrial product and service marketers who were increasingly using sport as a promotional vehicle for their (non-sport related) products or services. This view that sport marketing is the marketing of a company's image or products/services through sport is too narrow but explains why certain marketing texts, consultants and corporate decisionmakers confuse sport sponsorship with sport marketing.

This confusion between sport marketing management as a broad concept and sponsorship management as an element of sport marketing is not fully clarified by sport marketing texts either. Desk research uncovered only a handful of books undier the title sport marketing (Mullin, Hardy \& Sutton, 1993; Mullin, Hardy, \& Sutton, 2000; Blackshaw \& Hogg, 1993; Stotlar, 1993; Brooks, 1994; Graham, Goldblatt \& Delpy, 1995; Schaaf 1995; Helitzer, 1996 Pitts \& Stotlar, 1996; Schlossberg, 1996; Shilbury, Quick \& Westerbeek, 1998; Shank, 1999; Pope \& Turco, 2001).

These authors have a wide view on what sport marketing really means. Brooks (1994) focuses very heavily on the management of sport sponsorships. Some of the authors such as Brooks (1994) (strategic sponsorship planning), Schaaf (1995) and Schlossberg (1996) do not really identify a structured sport marketing strategy, programme or mix. Stotlar (1993) supports the orthodox marketing mix but only Mullin et al (1993) extend the traditional marketing mix to specify a sport-related marketing mix. Shilbury et al (1998) is the only authors with a strategic sport marketing approach. Shank (1999) extends his approach to cover strategic marketing applications to sport marketing. Pope and Turco (2001) apply the traditional marketing mix to events and do not identify a sport marketing mix

Evans, James and Tomes (1996)

summarise sport marketing as:

- the use of sport as a promotional vehicle for consumer and industrial goods and services;

- the marketing of sports products, services and events to consumers of sport; and

- sport associations adapt a market orientation to remain commercially viable in an intensively competitive environment.
More substantial discussions on TOWARDS A DEFINITION OF sponsorships are found in texts on marketing communication (Dibb et al., 1994; Adcock, Bradfield, Halborg \& Ross, 1995; Wilmshurst 1995; Siegel, 1996). Bennett, Lamm \& Fry (1988) mention sponsorship as part of sales promotion; Belch \& Belch (2001) define event sponsorship as a consumer-orientated sales promotion; Cannon (1992) mentions sport as a promotion application on television. Lancaster \& Massingham (1993) mention sponsorship as a public relations technique and Hill (1994) discusses event sponsorship as a PR activity. Kotler (1994) identifies the sponsoring of a sport event as a major marketing public relations (MPR) tool. Zikmund and d'Amico (1996) view event sponsorship as a publicity generating and image-building exercise.

It is therefore surmised from the above that there is a dire need for literatures in this vital area. African academics should produce marketing, marketing communication, sport marketing and sport sponsorship textbooks that serve the needs of African sport.

\section{SPORT MARKETING}

Sport marketing as a theoretical construct has many confusing alternatives. Pitts and Stotlar (1996) state that "academicians have not yet agreed on what sport marketing is". Some texts create the impression that sport marketing equals sport sponsorship while uncertainty exists as to whether a unique sport-related marketing mix applies or whether sport marketing is an application from basic marketing such as retail marketing.

There is also lack of consensus on the correct terminology with regards to sport (singular) or sports (plural) marketing, which further confuses the issue. In this paper the term sport marketing (without an 's) is preferred. Mullin, Hardy and Sutton (1993) argue that "sports marketing" tends to characterise the industry as a mass of uncoordinated segments without commonality. The singular form is therefore preferred because all sport segments should be regarded as a homogeneous entity.

The first definition of sport(s) marketing was coined by Kesler (1979) and stated that sport marketing describes the activities 
of consumer and industrial product and service marketers who were increasingly using sport as a promotional vehicle for their (non-sport related) products or services. This view that sport marketing is the marketing of a company's image or products/services through sport is too narrow but explains why certain marketing texts, consultants and corporate decisionmakers confuse sport sponsorship with sport marketing.

This confusion between sport marketing management as a broad concept and sponsorship management as an element of sport marketing is not fully clarified by sport marketing texts either. Desk research uncovered only a handful of books incier the title sport marketing (Mullin, Hardy \& Sutton, 1993; Mullin, Hardy, \& Sutton, 2000; Blackshaw \& Hogg, 1993; Stotlar, 1993; Brooks, 1994; Graham, Goldblatt \& Delpy, 1995; Schaaf 1995; Helitzer, 1996; Pitts \& Stotlar, 1996; Schlossberg, 1996; Shilbury, Quick \& Westerbeek, 1998; Shank, 1999; Pope \& Turco, 2001).

These authors have a wide view on what sport marketing really means. Brooks (1994) focuses very heavily on the management of sport sponsorships. Some of the authors such as Brooks (1994) (strategic sponsorship planning), Schaaf (1995) and Schlossberg (1996) do not really identify a structured sport marketing strategy, programme or mix. Stotlar (1993) supports the orthodox marketing mix but only Mullin et al (1993) extend the traditional marketing mix to specify a sport-related marketing mix. Shilbury et al (1998) is the only authors with a strategic sport marketing approach. Shank (1999) extends his approach to cover strategic marketing applications to sport marketing. Pope and Turco (2001) apply the traditional marketing mix to events and do not identify a sport marketing mix.

Evans, James and Tomes (1996) summarise sport marketing as:

- the use of sport as a promotional vehicle for consumer and industrial goods and services;

- the marketing of sports products, services and events to consumers of sport; and

- sport associations adapt a market orientation to remain commercially viable in an intensively competitive environment.
Van Heerden (1998) formulated three scenarios that contextualise sport marketing and indicate that sport marketing has a three-pronged focus.

- the marketing of sport products and services, such as equipment and facilities, which might be consumed by professional athletes or amateur hackers; (Scenario 1)

- the marketing of an organisation through its association, such as a sponsorship, with sport events, teams or individuals; (Scenario 2) and

- the way sport bodies and codes market themselves and their events to attract sponsorships participants, spectators, funding, and corporate involvement (Scenario 3)

According to van Heerden (1998) sport marketing therefore can range from lifestyle or leisure activity marketing (Scenario 1) to a corporate marketing strategy which includes some elements of sport marketing in the marketing mix (Scenario 2) to affinity marketing and/or event marketing (Scenario 3). The exact make-up of a generic sport marketing mix is therefore quite difficult and sport sponsorships will have a different application in each scenario. In scenario 1 a sport sponsorship by a marketer of sport products and services can be directed at specific user-target markets for example Speedo sponsoring the national swimming championship. Scenario 2 covers the situation where a non-sport related sponsor can use a sport sponsorship to market itself or its products or services to sport-related target markets such as Adidas being the clothing sponsor to sport teams. In scenario 3 the sporting bodies and codes and sporting personalities are the main beneficiaries of sponsorships. It can be argued that their level of marketing orientation and/or their marketing success rate (and perhaps professional behaviour) might influence their attractiveness to sponsors.

The notion that an organisation can market itself through its association, such as a sponsorship, with sport events, teams or individuals should therefore not stand on its own as a definition of sport marketing some organisations are involved in sport and others not. Its involvement in sport is derived from its overall marketing strategy. 
Shank (1999) defines sport marketing as "the specific application of marketing principles and processes to sport products and to the marketing on non-sport products through association with sport". He also defines the sport marketing mix as involvement in promotional activities such as advertising, sponsorships, public relations, and personal selling and involvement in product and services strategies, pricing decisions, and distribution issues (Shank, 1999).

A combination of the definition of sport marketing by Shank (1999); the threescenario approach of van Heerden (1998); and the view of Evans et al (1996) is postulated as a comprehensive definition of sport marketing. Combining these views would lead to the following definition of sport marketing that alludes to three different constructs:

Sport marketing is the specific application of theoretical marketing principles and processes to sport products and services (marketing of African sport); the marketing of non-sport and sport-related products and services through an association - such as a sponsorship - with sport (marketing through African sport); and the marketing of sport bodies and codes, their personalities, their events, their activities, their actions, their strategies and their image (marketing by African sport).

Research perspectives on each of the three constructs will be discussed in the following section of this paper.

\section{THE THREE-CONSTRUCT \\ APPROACH TO SPORT \\ MARKETING}

Based on the proposed definition the following constructs have been identified:

- Construct 1: The marketing of sport products and services, such as equipment and facilities consumed by professional athletes or amateur hackers;

- Construct 2: The marketing of a company's image, products and/or services through its association, such as a sponsorship, with sport events, teams or individuals;

- Construct 3: The way sport bodies and codes market themselves and their events to attract participants, spectators, funding, community support and corporate involvement. An analysis of these constructs now follows:

\section{Conceptualising Constructs 1 and 2}

Construct 1: The marketing of sport products and services, such as equipment and facilities - consumed by professional athletes or amateur hackers.

Sport marketing in Africa consists of all activities designed to meet the needs and wants of African sport consumers. Two major thrusts can be identified:

- the marketing of sport products and services directly to consumers of sport, and

- $\quad$ the marketing of other (non-sport related) consumer and industrial products and services through the use of sport promotions (Mullin, 1993).

The latter aspect might be derived from a company's overall marketing strategy and should therefore not stand on its own as a definition of sport marketing - some company's are involved in sport and others not. It must be noted here that sport consumers include all people involved in sport, including those who play, officiate, watch, listen, read, collect or have a specific interest in sport.
Construct 2: The marketing of a company through its association such as a sponsorship, with sport events, teams or individuals.

Kesler's (1979) definition needs further scrutiny in order to put sport sponsorship as a theoretical construct in its proper perspective. It is this author's view that:

- sport sponsorship is an element of an overall integrative marketing strategy and should not be deemed $_{c . .}$ to be an exclusive domain of a mythical sport marketing strategy;

- sport sponsorship is an option available to be included as an integrative element of the promotion or marketing communication mix of a corporate marketing mix;

- $\quad$ sport sponsorship supports or is supported by the other promotion or marketing communication elements: advertising, sales promotion, personal selling, publicity and/or public relations.

An overview of literature needs to be done to uncover any relationships between marketing and communication elements relevant to sport marketing. A review and critical analysis of such literature should 
lead to the formulation of a relevant sport marketing approach to cover Scenarios 1 and 2.

Developing a sport related marketing mix to cover Construct 1 and 2

At first one's marketing instinct urges that a sport-related marketing mix should be developed to cover the theoretical base of Constructs 1 and 2. Desk research revealed that a lack of discussion and research exist on the relationship between different elements of the sport-related marketing mix and which elements should be included in such a mix. This unfortunately leads to a lack of understanding on the interdependence between such elements.

It is this avihor's view that the spotlight should be focused on how specific elements (product, price, place and integrated communication - sponsorships, publicity, media relations and advertising) differentiate a sport related marketing mix from the traditional marketing mix.

The traditional marketing mix and some important issues regarding its conceptualisation need to be revisited before its application to sport marketing can be understood. The traditional marketing mix should be scrutinised to evaluate its extension to sport marketing. The traditional marketing mix is seen to consist of four major elements "Ps": price, product, promotion (or marketing communication), and place (distribution) (Kotler, 1989; McCarthy \& Perreault, 1990; Kotler \& Armstrong, 1993 and Stanton, Etzel \& Walker, 1994). An elaboration of ridiculous new sets of Ps, such as the 5 Ps of insurance (Promotion, price, package development, professionals and personal selling) (Pillsbury 1989) and the 5 Ps of cellular telephones (product, place, price, promotion and predatory practices) (Stanton, 1988) have been identified in marketing literature. Only Mullin et al (1993) have yet tried to define a sport-related marketing mix that deviates from the traditional marketing mix. They have added promotional licensing to promotion and public relations as a separate " $\mathrm{P}$ " to the four traditional "Ps". Proper research is needed to scrutinise the sport-related marketing mix elements as identified by Mullin et al. (1993), for viability, all-inclusiveness and whether other elements still have to be/can be measured and quantified.

At this stage the scientific constructing of a unique sport-related marketing mix is definitely inconclusive - the traditional marketing mix and the services marketing mix are the only truly scientific and realistic approaches available - maybe the sport-related marketing mix should be based on the former and in relevant situations some elements can be borrowed from the latter.

It is this author's view that the scientific development of a sport-related marketing mix should focus on how the marketing communication mix should be adapted to differentiate sport marketing from any other marketing applications such as retail marketing and services marketing.

\section{Basis for Formulating a Sport-related} Marketing Approach

After an exhaustive but very enlightening analysis of a number of marketing texts a number of viewpoints have been developed:

- The integrated marketing communication (IMC) approach also applies to sport.

Belch and Belch (1995) discuss IMC as a broader approach to replace the traditional marketing communication or promotion mix approach and could equally be applied to sport marketing.

- The public relations issue
Some debate amongst different authors focuses the spotlight on whether public relations and/o publicity should be included in the traditional marketing mix (and equally to the sport-related marketing mix). The traditional marketing mix was developed by McCarthy (Van Waterschoot \& van den Bulte, 1992). At first the promotion mix consisted of sales promotion, personal selling, advertising and publicity. More recently some authors substituted publicity with public relations or public relations was added - either through:

- a lack of differentiation between the two;

- defining the two concepts incorrectly; and/or

- a broadening of the view that publicity is too simplistic.

This issue need not be a defeating exercise. This paper proposes to follow the middle course. Public relations and marketing are two different domains of organisational functions but very interdependent. 
An interesting spin-off of the debate surrounding PR's role in the marketing strategy is the development of the concept of marketing public relations (MPR) (Harris, 1993; Henry, 1995; Bovée, Houston \& Thill, 1995; Marken, 1995; Hutton, 1996; Kotler \& Armstrong, 1997; Solomon \& Stuart, 1997). The view should be explored that corporate public relations support the sport marketing strategy but that concepts such as publicity and marketing public relations are elements of the promotion construct of the sportrelated marketing mix.

\section{Other Aspects of the Sport-related Marketing Mix}

Within a strategic approach a product or service is a very strong bonding facto between the marketing mix elements. In sport marketing, sport as a product is difficult to define. Sport products such as Nike running shoes are marketed through the traditional product marketing approach It is interesting to note that a lifestyle marketing approach has led to the positioning of sport equipment and facilities as niche or lifestyle products and services.
Sport participation in Africa, as athlete or spectator, can be physical or emotional. This is where the problem of defining sport marketing lies. African sport as product contains both tangible and intangible features. Intangible features such as being a fan of Zamalek, Kaizer Chiefs or Manchester United is internally generated but cannot be separated from physical properties such as living close to the team grounds, attending a sport event, or collecting team paraphernalia.

The following sport-related marketing mix aspects should also be researched in future to fully cover the theoretical development of Scenarios 1 and 2:

- how and why African sport as a product/service and sport products are consumed;

shared experiences between spectators and athletes;

- the unpredictability of the outcome of the match or event creates an excellent marketing environment (although its is assumed that scandals such as the Hansie Cronje cricket match rigging debacle, the Ellis Park soccer disaster, and performance inhibition (deliberately losing a cricket match

or not really trying to save a goal) marketing should be analysed and could is more the exception than the form the basis of further research projects:

rule);

- how to price sport participation in Africa where many fans have limited funds to pay for transport, food and drink and a ticket (athletes, spectators and sponsors);

- place decisions in Africa such as facility location, ticket availability, package tours and media coverage;

- African sport and leisure services with regards to intangibility, inseparability, variability and perishability;

- managing service quality in the African sport industry; and

- the application of the services marketing mix to African sport.

Sport sponsorship management is the glamour side of sport marketing. It is the view of this author that return on investment (ROI), i.e. ratio of profits to sum invested, and marketing effects achieved should receive much more attention in marketing research and literature.

To conclude the discussion on Scenarios 1 and 2 the following applications from basic
- the marketing of sport products such as running shoes could follow the traditional or a niche or lifestyle

- marketing approach;

the marketing of sport personalities could follow the approach described by Kotler and Armstrong (1993) and Churchill and Peter (1995) of person marketing or Solomon and Stuart (1997) of people marketing;

- the marketing of sport as a generic construct could follow the approach of marketing; it is a leisure activity; the marketing of a company's products or services (related to sport or not) is usually associated with sport sponsorships and could be an element of the company's promotion strategy which is derived from the general marketing strategy. It is therefore not a sport marketing strategy that stands on its own;

w Niche marketing and relationship marketing also apply to sport; and

- New strategies such as affinity marketing, ambush marketing and 
fantasy marketing is peculiar to sport.

Research reports on such issues would greatly enhance and expand the body of African sport marketing knowledge.

Construct 3: The way sport bodies and codes market themselves and their events to attract participants, spectators, funding, and corporate involvement (affinity marketing and/or event marketing).

Sport bodies and codes, such as the Nigerian Football Association or the South African Football Association, often the main beneficiaries of sponsorships, don't only need sponsors support but also support from the media, the community, fans and the government to be suecessful. Much more extensive research is needed to understand how a wide range of marketing constructs, namely services marketing, personality marketing, corporate image marketing, event marketing, leisure marketing, affinity marketing, fantasy marketing, and relationship marketing, can be applied to African sport.

The marketing of African sport codes and sport bodies could therefore range from event marketing to affinity marketing (fan clubs or membership programmes) and should also for example follow the same approach as that of marketing a company and its image. The image of a soccer team or a soccer player has to be measured to enable the sport marketer to develop public relations and marketing campaigns to promote the activities of such a team or player. Teams have been given nicknames such as the Nigerian Super Eagles or the South African Bafana Bafana to promote fan loyalty. Real and long-lasting fan loyalty will also be nurtured by developing a winning culture for African soccer teams at, for example, the World Cup.

\section{CONCLUSION}

The sport industry can be a major contributor to Africa's economic development. It was therefore a pity that the 2006 Soccer World Cup was awarded to Germany. Had the tournament been awarded to South Africa, the Southern African region and the entire African continent could have profited in economic and financial terms. Hopefully, this could be achieved if South Africa or any other African country is awarded the tournament by 2010 .
The performance of Africa's sport teams and heroes also influence the self-esteem and general mood of African people in crime-ridden and poverty-stricken environments. The performance of Africa's sport marketing fraternity is equally important to ensure the well-being of sport products and services and the support that different sport codes and bodies generate in Africa.

Proper development of sport marketing skills and abilities, that relate to African conditions, are therefore important to tie up all loose ends. This can only be achieved by African academics and practitioners who pay more attention to the development of a body of knowledge for sport marketing that applies to Africa.

\section{ACKNOWLEDGEMENT}

This article is based on a paper presented at the Sport Science Congress held at the University of Pretoria, South Africa in October 2002.

\section{REFERENCES}

Adcock, D., Bradfield, R., Halborg, A. \& Ross, C. (1995). Marketing Principles and Practice (2 ${ }^{\text {nd }}$ Edition). London, UK: Pitman Publishing.
Belch, G.E. \& Belch, M.A. (1995). Introduction to Advertising and Promotion - An Integrated Marketing Communication Perspective. USA: Irwin.

Belch G.E. \& Belch, M.A. (2001). Introduction to Advertising and Promotion - An integrated marketing communication perspective. Fifth Edition. USA: Irwin.

Bennett, P.D., Lamm, R.P. \& Fry, R.A. (1988). Marketing. Boston, USA: McGraw-Hill.

Blackshaw, I. \& Hogg, G. (Eds.) (1993). Sports Marketing Europe - The Legal and Tax Aspects. Cambridge, UK: Blackwell Publishers.

Bovée, C.L., Houston, M.J. \& Till, J.V. (1995). Marketing (2 $2^{\text {nd }}$ ed.). USA: McGraw-Hill, Inc.

Brooks, C.M. (1994). Sports Marketing. USA: Prentice-Hall.

Cannon, T. (1992). Basic Marketing Principles and Practice ( $2^{\text {nd }}$ ed.). Boston, USA: McGraw-Hill.

Churchill, G.A. Jr. \& Peter, J.P. (1995) Marketing - Creating Value for Customers. Homewood, Illinois, USA: Austen Press Irwin.

Dibb, S., Simkin, L., Pride, W.M., \& Ferrell, O.C. (1994). Marketing Concepts, and Strategies, ( $2^{\text {nd }} \mathrm{ed}$.). Boston, USA: Houghton Miflin Company.

Evans, A., James, T. \& Tomes, A. (1996). Marketing in UK Sport Associations. The Services Industries Journal, 16 (2), 207 222 (April).

Furlong, R. (1994). Tobacco Advertising Legislation and the Sponsorship of Sport. 
Australian Business Law Review, 22, 159 - 189 (June).

Graham, S., Goldblatt, J.J. \& Delpy, L. (1995). The Ultimate Guide to Sport

Event Management and Marketing. USA: Irwin Professional Publishing.

Harris, T.L. (1993). The Marketer's Guide to Public Relations. New York, USA: John Wiley \& Sons Inc.

Helitzer, M. (1996). The Dream Job: Sports Publicity, Promotion and

Marketing ( $2^{\text {nd }}$ ed). Athens, Ohio (USA): University Sport Press.

Henry, R.A. Jr. (1995). Marketing Public Relations - The Hows that Make it Work. Iowa State University Press, Iowa, USA.

Hill, N. (1994). Marketing ( $2^{\text {nd }}$ ed). Avon, UK: Business Education Publishers.

Hutton, J.G. (1996). Integrated marketing communications and the evolution of marketing thought. Journal of Business Research, 37 (3), 155-162 (November).

Kesler, L. (1979). Man created ads in sport's own image. Advertising Age, pp. 5-10, (August 27).

Kotler, P. \& Armstrong, G. (1993) Marketing an Introduction ( $3^{\text {rd }}$ ed). New Jersey, USA: Prentice-Hall.

Kotler, P. \& Armstrong, G. (1997) Marketing an Introduction ( $4^{\text {th }}$ ed). New Jersey, USA: Prentice-Hall.

Kotler, P. (1989). From Mass Marketing to Mass Communication. Journal of Planning Review, 17 (5), 10-13,47 (Sep/Oct).
Kotler, P. (1994). Marketing Management - Analysis, Planning, Implementation, and Control $\left(8^{\text {th }} \mathrm{ed}\right)$. New Jersey: PrenticeHall.

Lancaster, G. \& Massingham, L. (1993). Essentials of Marketing. Marketing Series. London, UK: McGraw-Hill.

Marken, G.A. (1995). Marketing public relations: lead, follow or get out of the way. Public Relations Quarterly, 40 (1),

47-48 (Spring).

McCarthy, E.J. \& Perreault, W.D. Jr. (1990). Basic Marketing (5 $5^{\text {th }}$ ed). Homewood, Illinois: Irwin.

Meenaghan, T. (1996). Ambush Marketing - A Threat to Corporate Sponsorship. Sloan Management Review

$103-113$ (Fall).

Mullin, B.J., Hardy, S. \& Sutton, W.A. (1993). Sport Marketing. USA: Human Kinetics Publishers.

Mullin, B.J., Hardy, S. \& Sutton, W.A (2000). Sport Marketing. Champaign, IL Human Kinetics Publishers.

Parks, J.B. \& Zanger, B.R.K. (1990). Spont and Fitness Management. USA: Human Kinetics Publishers.

Pillsbury, D.H. (1989). The Trust Factor Is the Key to This Agency's Marketing Success. Rough Notes, 132 (9), 10-13.

Pitts, B.G. \& Stotlar, D.K. (1996). Fundamentals of Sport Marketing. USA: Fitness Information Technologies.

Pope, N \& Turco, D. (2001). Sport and Event Marketing. NSW, Australia McGraw-Hill
Pride, W. M. \& Ferrell, O. C. (1993) Marketing Concepts and Strategies $\left(8^{\text {th }}\right.$ ed). Boston, USA: Houghton Miflin Company

Schaaf, P. (1995). Sports Marketing. USA: Prometheus Books.

Schlossberg, H. (1996). Sports Marketing. Massachusetts, USA: Blackwell Publishers.

Shank, MD. (1999). Sports Marketing - A Strategic Perspective. New Jersey, USA Prentice-Hall.

Shilbury, D., Quick, S. \& Westerbeek, H. (1998). Strategic Sport Marketing. Australia: Allen \& Unwin.

Siegel, C.F. (1996). Marketing Foundations and Applications. Chicago, Illinois, USA: Irwin Mirror Press.

Solomon, M.R. \& Stuart, E.W. (1997) Marketing - Real People Real Choices. New Jersey, USA: Prentice-Hall.

Stanton, J. (1988). The Five Ps of Marketing Cellular. Cellular Business, (2), 32-35 (February)

Stanton, W.J., Etzel, M.J. \& Walker, B.J. (1994). Fundamentals of Marketing $\left(10^{\mathrm{H}}\right.$ ed) International Edition. New York USA: McGraw-Hill.

Stotlar, D. (1993). Successful Sport Marketing. USA: Brown \& Benchmark.

Thwaites, D. (1995). Professional footbal sponsorship - profitable or profligate? International Journal of Advertising, 14 $149-164$

Van der Walt, A. \& Machado, R. (Eds) (1992). New Marketing Success Stories.
Halfway House, South Africa: Southern Book Publishers.

Van der Walt, A. Strydom, J.W. Marx, S. \& Jooste, C.J. (1996). Marketing Management. Kenwyn, Pretoria, South Africa: Juta Books.

Van Heerden, C.H. (1998). A research approach to sport marketing in South Africa. Proceedings of the 1998 IMM Marketing Educator's Conference, pp. 352-390, Cape Town, South Africa (April 29-30).

Van Heerden, C.H. (2001). Factors Affecting Sport Sponsorship DecisionMaking in South Africa. Unpublished doctoral thesis, University of Pretoria, South Africa.

Van Waterschoot, W. \& Van den Bulte, C. (1992). The 4P Classification of the Marketing Mix Revisited. Journal of Marketing, 56 (4), 83-93.

Wilmshurst, J. (1995). The Fundamentals and Practice of Marketing. Oxford, UK: Butterworth-Heinemann Ltd.

Zikmund, W.G. \& d'Amico, M. (1996) Marketing $\left(5^{\text {th }}\right.$ ed). Minneapolis, USA: South-West Publishing. 